\title{
Handgrip strength, functionality and plasma levels of IL-6 in elderly women
}

\author{
Força de preensão manual, funcionalidade e \\ níveis plasmáticos de IL-6 em idosas
}

\author{
Daniele S. Pereira $^{[\mathrm{a}]}$, Viviane F. Cipriano ${ }^{[\mathrm{b}]}$, Juleimar S. C. Amorim ${ }^{[\mathrm{c}]}$, Bárbara Z. Queiroz ${ }^{[\mathrm{b}]}$, \\ Diogo C. Felício ${ }^{[b]}$, Leani S. M. Pereira ${ }^{[b] *}$ \\ [a] Universidade Federal de Alfenas (Unifal), Alfenas, MG, Brazil \\ [b] Universidade Federal de Minas Gerais (UFMG), Belo Horizonte, MG, Brazil \\ [c] Universidade Estadual de Londrina (UEL), Londrina, PR, Brazil
}

\begin{abstract}
Introduction: Aging is associated with a chronic low-grade inflammatory process characterized by an increased production of inflammatory mediators. These elevated levels are predictors for muscle function (sarcopenia) and deterioration of physical performance in the elderly. Objective: To investigate the correlation between sarcopenia, functional capacity, and interleukin-6 levels. Materials and methods: This crosssectional study assessed a convenience sample of elderly individuals $(n=130)$ using a handgrip dynamometer $\left(\mathrm{JAMAR}^{\mathrm{TM}}\right)$, and the functional capacity test was performed by sitting and standing. Interleukin- 6 levels were determined using high sensitivity ELISA kits. Spearman correlation coefficient was used to assess the correlation between these variables, at a significance level $(\alpha)$ of 0.05 . Results: There was significant
\end{abstract}

* DSP: PhD, e-mail: daniele.sirineu@gmail.com

VFC: specialist, e-mail: vivi_cipriano@yahoo.com.br JSCA: MSc, e-mail: juleimar@yahoo.com.br

BZQ: PhD, e-mail: babzille@gmail.com

DCF: PhD candidate, e-mail: diogofelicio@yahoo.com.br

LSMP: PhD, e-mail: leanismp.bh@terra.com.br 
inverse correlation between strength and function ( $\mathrm{rS}=-0.273, \mathrm{p}=0.002)$ such that elderly individuals with lower peak force took longer to perform the sit-to-stand test, in contrast with the relationship between plasma interleukin-6 levels and strength ( $\mathrm{rS}=-0.043, \mathrm{p}=0.624)$ or functionality $(\mathrm{rS}=-0.060, \mathrm{p}=0.501)$. Conclusion: The outcome measures analyzed could predict the decline in muscle strength and functional capacity, and may be indicative of sarcopenia in elderly individuals. There was no correlation between the interleukin-6 levels and the grip strength and functional capacity of the sample investigated.

Keywords: Sarcopenia. Muscle strength dynamometer. Interleukin-6. Aged.

\section{Resumo}

Introdução: O envelhecimento está relacionado a uma ativação crônica sublimiar do processo inflamatório, com aumento da produção de mediadores inflamatórios, cujos níveis elevados são preditores do declínio da função muscular (sarcopenia) e capacidade funcional na população idosa. Objetivo: Verificar a correlação entre sarcopenia, capacidade funcional e interleucina-6. Materiais e métodos: Estudo transversal, amostra de conveniência de idosas da comunidade $(n=130)$, em que se avaliou a força de preensão manual com dinamômetro de JAMAR囚, e a capacidade funcional pelo teste de sentar e levantar da cadeira cinco vezes. A interleucina-6 foi analisada por meio de kits de alta sensibilidade, pelo método de ELISA. Utilizou-se o coeficiente de Spearman para verificar a correlação entre as variáveis, considerando o nível de significância $(\alpha)$ de 0,05. Resultados: Houve correlação significativa e inversa entre a força manual e o teste funcional ( $r S=-0,273$; $p=0,002)$, ou seja, idosas com menores picos de força apresentaram pior desempenho no teste de sentar $e$ levantar. Não foi observada correlação entre as demais variáveis: índices plasmáticos de interleucina-6 e força ( $r S=-0,043 ; p=0,624)$ e funcionalidade ( $r S=-0,060 ; p=0,501)$. Conclusão: As medidas de desfechos analisadas conseguiram rastrear a diminuição da força muscular e da capacidade funcional, podendo ser indicativas de sarcopenia em idosas. Os níveis de interleucina-6 não se correlacionaram com a força de preensão manual e com a capacidade funcional na amostra avaliada.

Palavras-chave: Sarcopenia. Dinamômetro de força muscular. Interleucina-6. Idosos.

\section{Introduction}

In contrast to developed countries, Brazil's aging population has increased rapidly over the last few decades (1). Elderly individuals experience not only various age-related conditions, but also a physiological process known as senescence, which can considerably worsen their clinical conditions (2). Among these, sarcopenia is particularly important.

Sarcopenia is characterized by the slow and progressive loss of muscle mass, strength, quality, and quantity, independent of the presence of diseases, even in physically active individuals (3). However, the mechanisms underlying sarcopenia are unclear, and it is also unclear if it causes or is caused by other medical conditions in elderly individuals.

There is evidence that inflammatory mediators such as tumor necrosis factor-alpha (TNF- $\alpha$ ), interleukin (IL-6), C-reactive protein, and IL-10 interact with the hormonal changes inherent to aging, thus causing a decline in physical activity and fat replacement of muscles (4), which simultaneously lead to volumetric muscle loss (5). High levels of these cytokines were established as predictors of chronic diseases, functional disability, and death among elderly individuals (3). TNF- $\alpha$ and IL- 6 are highly specific to stimulating myosin proteolysis of the heavy chain and synergistically contribute to the worsening of sarcopenia (6).

To evaluate the health conditions in elderly individuals at risk of sarcopenia, it is necessary to quantify skeletal muscle mass using dual-energy X-ray absorptiometry (DXA), magnetic resonance imaging, and bioelectrical impedance analysis. Imaging methods offer the advantage of regional quantification of individual muscle mass (6). In this context, it is appropriate to use specific tests for physical capacity evaluation in elderly individuals, according 
to the International Classification of Functioning, Disability and Health model proposed by the World Health Organization (WHO) (7). The sit-to-stand test (STS) using a chair and handgrip strength (HGS) have been identified as strong predictors of disability and sarcopenia in senescence (8).

A widely used tool for estimating overall muscle strength in elderly individuals (9), HGS has shown a positive correlation to self-perceived fatigue (10) and increasing plasma levels of IL-1, IL-6, and IFN- $\gamma$ in elderly individuals $(11,12)$. There is a statistically significant relationship between morbidity (13, 14), longevity (15), and emotional and overall health status and mortality $(16,17)$. In contrast, the SST incorporates a routine activity performed in daily life, which provides important information on the muscle power of the lower limbs and balance (18). Any changes in performance are correlated to falls (18). Both tests are quick, easy to perform in clinical practice, and can be performed in a confined space. They measure muscle strength of the lower limbs (19), functionality (20), mobility $(21,22)$, and accelerated decline in activities of daily living (ADL) (16).

The direct clinical consequences of sarcopenia include physical and functional disability, decline in quality of life and independence (13), and impaired performance of the ADL such as mobility (4) and gait speed. Physical disability is considered one of the worst consequences of aging, and its prevention is a research priority (3).

Given the impact of sarcopenia on the functional capacity of elderly individuals and the influence of inflammatory mediators on these changes, the aim of this study was to investigate the correlation between sarcopenia, as assessed by HGS and SST, and the IL-6 plasma levels. These complex interrelationships are significant for identifying sarcopenic individuals through their functional limitations, as well as determining the relationship between disability and the silent effects of inflammatory mediators during senescence. In addition, sarcopenic elderly individuals are at risk of age-related diseases, because of changes related to exacerbated immunosenescence. We hypothesized that HGS and STS results are related to changes in plasma levels of cytokines. However, if unverified, it would indicate that other factors such as specific sample characteristics may influence the relationship between the studied variables.

\section{Materials and methods}

Study design and ethical aspects

This observational cross-sectional included a sample of elderly women living in the city of Belo Horizonte. After approval by the ethics committee of UFMG (ETIC: 38/2010), all participants read and signed informed consent forms agreeing to participate in the study.

\section{Subjects}

The sample selection was conducted by convenience with the participants recruited from health centers and elderly social groups, and through publication in local newspapers $(n=130)$. The participants were aged $\geq 65$ years, sedentary, and residents of the community.

The exclusion criteria were cognitive changes determined by the mini-mental state examination, considering the cut-off points proposed by Bertolucci et al. (23) (13 points, illiterate; 18 points, individuals with $<8$ years of education; 26 points, individuals with $\geq 8$ years of education); severe sensory changes that prevented test application; any type of inflammatory disease in the acute phase; neoplasia within the last 5 years; use of anti-inflammatory drugs or drugs targeting the immune system; and history of orthopedic surgery, fracture in the last 6 months, or amputation of the upper and lower limbs. One hundred and thirty-four elderly women underwent screening, among whom three were excluded $(0.02 \%)$ because of cognitive impairment, whereas one $(0.007 \%)$ had a history of neoplasia. Therefore, 130 participants were finally in the study.

\section{Instruments}

A sociodemographic and structured clinical and functional questionnaire was used to retrieve information on age, marital status, education, personal income, clinical conditions (i.e., comorbidity, number and type of medications, body mass index, pain complaint) through personal interviews conducted by trained researchers. 
HGS was measured using the JAMAR ${ }^{\text {TM }}$ dynamometer, model PC5030JI, standardized by Rantanen et al. (14), following the measurement recommendations by Figueiredo et al. (24). Three maximum grip maneuvers were performed with the dominant hand, with one minute of rest between maneuvers. The average of the three measurements was reported in kilogram/force (kgf). High test-retest $(r \geq 0.80)$ and inter-rater $(\mathrm{r} \geq 0.97)$ reliability was reported for HGS was measured using Jamar ${ }^{\mathrm{TM}}$ (24).

Functional capacity of the elderly was evaluated by performing the SST. The women were seated in a 45-cm-high chair, with straight back without armrest, arms crossed over the trunk, hips and knees flexed at $90^{\circ}$, and feet flat on the floor. They were then instructed to stand up and sit down on the chair five times, each time at the highest possible speed. Meanwhile, the time spent in seconds to perform the task was recorded. Longer times to complete the task indicated worse functional capacity.

\section{Procedures}

For measurement of the serum IL-6 levels, $5 \mathrm{~mL}$ of blood was collected from the ulnar vein of the participants in vacutainers containing sodium citrate in a sterile environment. The procedure was performed by a qualified professional in the morning (between 8:00 and 10:00) to avoid the influence of circadian cycle changes. After collection, the vacutainers tubes were processed and centrifuged (Fanem) at 1,500 rpm for 15 minutes. The plasma was removed in a laminar flow using previously siliconized Pasteur pipettes, placed in sterile Eppendorf tubes, and stored in a freezer at $-80^{\circ} \mathrm{C}$. IL- 6 concentrations were analyzed using high sensitivity enzyme-linked immunosorbent assay kits (Quantikine HS, R\&D Systems Minneapolis). The sample analysis was performed using a microplate reader set to $490 \mathrm{~nm}$, with wavelength correction at $650 \mathrm{~nm}$. The review process was conducted in the Pain and Inflammation Laboratory and Aging Studies, Department of Physiotherapy of UFMG.

\section{Statistical analysis}

Descriptive statistical analysis was performed using measures of central tendency (mean and median) and variability (range and standard deviation). The
Kolmogorov-Smirnov test was used for distribution analysis of the normal data. Since both STS and IL-6 were not normally distributed, non-parametric tests were used for statistical analysis.

The Spearman correlation coefficient was used to verify the correlation between the STS results, HGS, and plasma levels of IL-6, considering a significance level $(\alpha)$ of 0.05 . Statistical analyses were carried out using the Statistical Package for Social Sciences (SPSS; version 15.0, Windows environment).

\section{Results}

The age of the volunteers ranged from 65 to 84 years, with a mean of 71.13 (4.5) years. Most women were married ( $\mathrm{n}=50 ; 38.5 \%)$, overweight $(\mathrm{n}=83$; $64.3 \%$ ) with a body mass index $>27 \mathrm{~kg} / \mathrm{m} \mathrm{(2)}$, and had low plasma IL-6 (mean $2.1 \mathrm{pg} / \mathrm{mL}$ ) levels. The sociodemographic and clinical characteristics of the study sample and the mean HGS, STS results, and plasma IL-6 levels are presented in Tables 1 and 2 , respectively.

The results showed a significant inverse correlation between the HGS and STS results $\left(\mathrm{r}_{\mathrm{S}}=-0.273\right.$; $\mathrm{p}=$ 0.002), such that elderly women with lower HGS had worse performance on the STS (more time to complete the test). There was no significant correlation between the plasma IL- 6 levels and HGS $\left(r_{S}=-0.043\right.$; $\mathrm{p}=0.624)$ or SST $\left(\mathrm{r}_{\mathrm{S}}=-0.060 ; \mathrm{p}=0.501\right)$ results.

Table 1 - Sociodemographic and clinical characteristics of the study participants

(To be continued)

\begin{tabular}{lcc}
\hline Features & $\mathrm{n}$ & $\%$ \\
\hline Marital status & & \\
Married & 50 & $38.5 \%$ \\
Single & 14 & $10.8 \%$ \\
Divorced & 11 & $8.5 \%$ \\
Widow & 55 & $42.3 \%$ \\
Education (years) & & \\
Illiterate & 11 & $8.5 \%$ \\
1 to 3 & 25 & $19.2 \%$ \\
4 to 7 & 55 & $42.3 \%$ \\
8 or more & 39 & $30 \%$
\end{tabular}


Table 1 - Sociodemographic and clinical characteristics of the study participants

(Conclusion)

\begin{tabular}{lcc}
\hline Features & $\mathbf{n}$ & $\%$ \\
\hline BMI $\left(\mathrm{kg} / \mathrm{m}^{2}\right)$ & & \\
$<22 \mathrm{~kg} / \mathrm{m}^{2}-$ thin & 10 & $7.7 \%$ \\
22 to $27 \mathrm{~kg} / \mathrm{m}^{2}-$ & 37 & $27.7 \%$ \\
eutrophic & & \\
$>27 \mathrm{~kg} / \mathrm{m}^{2}-$ & 83 & $64.6 \%$ \\
overweight & & \\
\hline
\end{tabular}

Note: $\%=$ percentage relative to the total number of elderly individuals; $\mathrm{BMI}=$ body mass index.

Table 2 - Interleukin-6 levels and functional capacity of the study participants

\begin{tabular}{lccc}
\hline Features & $\mathbf{n}$ & Mean (+SD) & Variation \\
\hline IL-6 (pg/mL) & 130 & $2.15( \pm 1.75)$ & $0.14-8.80$ \\
HGS (kgf) & 130 & $21.7( \pm 4.6)$ & $10-34.6$ \\
SST (seconds) & 130 & $15.3( \pm 3.8)$ & $9.0-26.2$ \\
\hline
\end{tabular}

Note: SD = Standard deviation; IL-6 = interleukin-6; HGS = handgrip strength; SST = sit-to-stand test..

\section{Discussion}

Aging-associated sarcopenia is a slow, progressive, and seemingly inevitable process. It directly influences the functional capacity of elderly individuals, and leads to a deterioration in health $(3,4,13)$. We found an inverse correlation between HGS and performance on the STS, which demonstrates that elderly women with lower muscle upper limb strength take longer time to perform the lower limb functional capacity test. A study by Visser et al. (25) previously investigated a sample of elderly patients aged $>65$ years and found similar results. An association between decreased HGS and a longer STS time was observed after statistical adjustment for age and height.

Decreased HGS has been previously identified as strong biomarker for aging $(12,16,20)$, indicating a negative impact of muscle strength loss on functional capacity (26). This measure provides an approximation of total body muscle force as it correlates with elbow flexion strength, extension force of the leg, and trunk strength (9).
There is an association between reduced HGS and difficulty in performing ADL (27). HGS appears to be an interesting predictor of mobility reduction. An investigation of 2,646 elderly participants, aimed at evaluating HGS to predict limitation in mobility among individuals aged $\geq 55$ years, revealed that a $21 \mathrm{kgf}$ cut-off point (67\% sensitivity and 73\% specificity) was sufficient for determining women at risk of deterioration in mobility (21). Similarly in a study including 904 healthy elderly individuals aged 67-84 years, Choquette et al. (22) and Visser et al. (25) revealed a positive correlation of mobility with HGS and running speed. According to Sallinen et al. (21), the linear relationship between muscle strength and mobility is better detectable among frail elderly individuals.

Studies indicate that muscle strength of both lower and upper limbs can be affected by the increase in IL-6 levels (11). Studies that assessed the correlation between knee flexion and extension strength using isokinetic dynamometer, gait speed, functional capacity test (STS), and plasma levels of IL-6, confirm that there is a negative correlation between these cytokines and the worst HGS torque peaks in elderly individuals. Unlike functional tests of gait speed and sitting and standing, there was no correlation (26) demonstrated, indicating that functionality encompasses a harmonious integration of various sensory motor systems and not only muscle tissue. Furthermore, results of the study by Oliveira et al. (26) indicated a catabolic action of inflammatory cytokines on muscle fibers. A study by Lustosa et al. (27) that assessed muscle strength with an isokinetic dynamometer (considered the gold standard tool for this measure) revealed an association between increased inflammatory cytokines and low muscular and functional performance in elderly individuals. It also demonstrated that exercise interventions may reverse the state of increased production of these cytokines. Increased levels of inflammatory mediators, particularly IL-6, have been associated with reduction in HGS among elderly women (11).

However, in our study, it was evident that there was no statistically significant correlation between IL-6 levels and HGS and STS results. One possible explanation is that the levels of this cytokine did not reach the threshold required to affect HGS and on the STS. Findings on the significance of IL-6 levels in the elderly population are conflicting. Cesari et al. (28) found that levels $>1.73 \mathrm{pg} / \mathrm{mL}$ were predictive of 
decreased muscle strength and functional capacity in older adults, whereas other authors report that IL-6 levels $>2.5 \mathrm{pg} / \mathrm{mL}$ or $>3.1 \mathrm{pg} / \mathrm{mL}$ were predictive of functional limitations $(5,29)$. In the present study, the mean serum IL-6 level was $2.1 \mathrm{pg} / \mathrm{mL}$.

The conflicting results observed in studies are probably due to the differences in sample characteristics, such as comorbidities, socioeconomic status, education level, and physical activity level. In this study, we selected elderly individuals, who despite being sedentary were active and performed ADL independently. The literature suggests that physically active individuals, although sedentary, lave lower plasma IL-6 concentrations.

The limitations of this study include the convenience method of sampling and inclusion of only female participants, which limit external validity and prevent generalization of results. In addition, the crosssectional design does not allow causal inferences about the relationships between the studied variables.

\section{Conclusion}

This study showed a significant and inverse correlation between HGS and performance on the sitto-stand test in elderly women. With the use of these simple and inexpensive tests, we could monitor the decrease in muscle strength and functional capacity, two variables that can be indicative of sarcopenia in elderly individuals when diminished. Plasma IL-6 level showed no significant correlation with HGS and SST. Future studies that control for the factors that influence the production of inflammatory markers, such as physical activity level, are needed to broaden the understanding of the effect of IL- 6 on muscle strength and functional capacity of functionally independent elderly individuals.

\section{References}

1. Caramano AA. Envelhecimento da população brasileira: uma contribuição demográfica. In: Freitas EV, Py L, editores. Tratado de geriatria e gerontologia. Rio de Janeiro: Guanabara Koogan; 2006. p. 88-105.
2. Rosa NMB, Queiroz BZ, Pereira DS, Santos MLS, Oliveira DM, Narciso FM, et al. Interleukin-6 plasma levels and socioeconomic status in Brazilian elderly community-dwelling women. Arch Gerontol Geriatr. 2011;53(2):196-9.

3. Doherty TJ. Invited review: aging and sarcopenia. J Appl Physiol. 2003;95(4):1717-27.

4. Visser M, Goodpaster BH, Kritchevsky SB, Newman AB, Nevitt M, Rubin SM. Muscle mass, muscle strength, and muscle fat infiltration as predictors of incident mobility limitations in well-functioning older persons. J Gerontol A Biol Sci Med Sci. 2005;60(3):324-3.

5. Ferrucci L, Harris TB, Guralnik JM, Tracy RP, Corti MC, Cohen HJ, et al. Serum IL-6 level and the development of disability in older persons. J Am Geriatri Soc. $1999 ; 47(6): 639-6$

6. Woo J, Leung J, Kwok T. BMI, body composition, and physical functioning in older adults. Obesity (Silver Spring). 2007;15(7):1886-94.

7. Organização Mundial da Saúde; Organização PanAmericana da Saúde. CIF: Classificação Internacional de Funcionalidade, Incapacidade e Saúde. São Paulo: Edusp; 2003.

8. Vreede PL, Samson MM, van Meeteren NLU, Duursma SA, Verhaar HJJ. Functional-task exercise versus resistance strength exercise to improve daily function in older women: A feasibility study. Arch Phys Med Rehabil. 2004;85(12):1952-61.

9. Rantanen T, Era P, Heikkinen E. Maximal isometric strength and mobility among 75-year-old men and women. Age Ageing. 1994;23(2):132-7.

10. Silva JP, Pereira DS, Coelho FM, Lustosa LP, Dias JMD, Pereira LSM. Fatores clínicos, funcionais e inflamatórios associados à fadiga muscular e à fadiga autopercebida em idosas da comunidade. Rev Bras Fisioter. 2011;15(3):241-8.

11. Pereira LS, Narciso FM, Oliveira DM, Coelho FM, Souza DG, Dias RC. Correlation between manual muscle strength and interleukin-6 (IL-6) plasma levels in elderly community-dwelling women. Arch Gerontol Geriatr. 2009;48(3):313-6. 
12. Xin DL, Harris MY, Wade CK, Amin M, Barr AE, Barbe MF. Aging enhances serum cytokine response but not task-induced grip strength declines in a rat model of work-related musculoskeletal disorders. BMC Musculoskelet Disord. 2011;12:63.

13. Lauretani F, Russo CR, Bandinelli S, Bartali B, Cavazzini C, Di Iorio A. Age-associated changes in skeletal muscles and their effect on mobility: an operational diagnosis of sarcopenia. J Appl Physiol. 2003;95(5):1851-60.

14. Rantanen T, Volpato S, Ferrucci L, Heikkinen E, Fried LP, Guralnik JM. Handgrip strength and cause-specific and total mortality in older disabled women: exploring the mechanism. J Am Geriatr Soc. 2003;51(5):636-41.

15. Rantanen T, Masaki K, He Q, Ross GW, Willcox BJ, White L. Midlife muscle strength and human longevity up to age 100 years: a 44-year prospective study among a decedent cohort. Age (Dordr). 2012;34(3):563-70.

16. Taekema DG, Gussekloo J, Maier AB, Westendorp RG, Craen AJ. Handgrip strength as a predictor of functional, psychological and social health: a prospective population-based study among the oldest old. Age Ageing. 2010;39(3):331-7.

17. Xue QL, Beamer BA, Chaves PHM, Guralnik JM, Fried LP. Heterogeneity in rate of decline in grip, hip, and knee strength and the risk of all-cause mortality: The Women's Health and Aging Study II. J Am Geriatr Soc. 2010;58(11):2076-84.

18. Bernardi M, Rosponi A, Castellano V, Rodio A, Traballesi M, Delussu AS, et al. Determinants of sit to stand capability in the motor impaired elderly. J Electromyogr Kinesiol. 2004;14(3):401-4.

19. Farias DL, Teixeira TG, Tibana RA, Balsamo S, Prestes J. A força de preensão manual é preditora do desempenho da força muscular de membros superiores e inferiores em mulheres sedentárias. Motricidade. 2012;8(S2):624-9.

20. Geraldes AAR, Oliveira ARM, Albuquerque RB, Carvalho JM, Farinatti PTV. A força de preensão manual é boa preditora do desempenho funcional de idosos frágeis: um estudo correlacional múltiplo. Rev Bras Med Esporte. 2008;14(1):12-6.

21. Sallinen J, Stenholm S, Rantanen T, Heliövaara M, Sainio P, Koskinen S. Hand-grip strength cut-points to screen older persons at risk for mobility limitation. J Am Geriatr Soc. 2010;58(9):1721-6.
22. Choquette S, Bouchard DR, Doyon CY, Sénéchal M, Brochu M, Dionne IJ. Relative strength as a determinant of mobility in elders 67-84 years of age. A NuAge study: nutrition as a determinant of successful aging. J Nutr Health Aging. 2010;14(3):190-5.

23. Bertolucci PH, Brucki SM, Campacci SR, Juliano Y. O Mini-Exame do Estado Mental em uma população geral: impacto da escolaridade. Arq Neuro-Psiquiatria. 1994;52(1):1-7.

24. Figueiredo IM, Sampaio RF, Mancini MC, Silva FCM, Souza MAP. Teste de força de preensão utilizando o dinamômetro Jamar. Acta Fisiatr. 2007;14(2):104-10.

25. Visser M, Deeg DJH, Lips P, Harris TB, Bouter LM. Skeletal muscle mass and muscle strength in relation to lower-extremity performance in elder men and women. J Am Geriatr Soc. 2000;48(4):381-6.

26. Oliveira DM, Narciso FM, Santos ML, Pereira DS, Coelho FM, Dias JM, et al. Muscle strength but not functional capacity is associated with plasma interleukin-6 levels of community-dwelling elderly women. Braz J Med Biol Res. 2008;41(12):1148-53.

27. Lustosa LP, Pereira LSM, Coelho FM, Pereira DS, Silva JP, Parentoni AN, et al. Impact of an exercise program on muscular and functional performance and plasma levels of interleukin 6 and soluble receptor tumor necrosis factor in prefrail community-dwelling older women: a randomized clinical trial. Arq Phys Med Rehabil. 2013;94(4):660-6.

28. Cesari M, Penninx BW, Pahor M, Lauretani F, Corsi AM, Rhys WG, et al. Inflammatory markers and physical performance in older persons: the InCHIANTI study. J Gerontol A Biol Sci Med Sci. 2004;59(3):242-8.

29. Ferrucci L, Pennix BWJH, Volpato S, Harris TB, Banden-Roche $\mathrm{K}$, Balfour J, et al. Change in muscle strength explains accelerated decline of physical function in older women with high interleukin-6 serum levels. J Am Geriatr Soc. 2002;50(12):1947-54.

Received: 08/14/2013 Recebido: 14/08/2013

Approved: 04/06/2015 Aprovado: 06/04/2015 
